\title{
PERKEMBANGAN TRANSAKSI MUDHARABAH DI PERBANKAN SYARIAH
}

\author{
Hendra Cipta \\ STAIN Syaikh Abdurrahman Siddik Bangka Belitung
}

\begin{abstract}
Mudaraba is a joint venture agreement between two parties, where the first party provides the entire capital is called shahibul mall and the second as the manager of the capital called mudharib. In other words, mudaraba is a term for the act of a person who entrusts his property to others to merchantability and split the profits for the two based on their agreement while losses to be borne by the property owner. Mudaraba concept was applied by sharia banks on savings accounts products, general investment accounts through deposits, special investment accounts, financing with the principle of profit sharing and mudaraba sukuk.

Mudaraba as a principle of profit sharing is still practiced by Islamic banks in Indonesia with revenue sharing not lead to a profit and loss sharing. Here we can see that Islamic banks are still not ready to share profits and losses with the customer, but every effort will face profit and loss. However, we hope that in the future Islamic banks could apply the concepts of profit and loss sharing.
\end{abstract}

Keywords: Mudharabah, Ekonomi Islam, Bank Syariah

\section{Pendahuluan}

Bunga bank dan riba di perbankan konvensional menjadi hal kontradiktif bagi masyarakat yang berusaha menghindarkan diri dari transaksi riba, sehingga sebagian masyarakat mencari perbankan yang halal yang luput dari komponen riba karena transaksi riba berseberangan dengan kaidah Islam. Oleh karena itu, perbankan syariah menawarkan akad mudharabah sebagai opsi jalan keluar dari transaksi yang memuat elemen non-halal (riba). Akad mudharabah ini sudah dituangkan dalam Pernyataan Standar Akuntansi Keuangan (PSAK) Nomor 105 ayat 4 yang menyatakan bahwa akad mudharabah 
merupakan perjanjian kolaborasi antara pemilik modal dengan fund manager di mana profit dibagi berdasarkan alokasi bagi hasil dan kerugian hanya akan ditanggung oleh pemilik modal. ${ }^{1}$

Mudharabah merupakan perjanjian kerjasama yang modal utamanya diinvestasikan oleh seorang investor atau sekelompok investor kepada pengelola usaha (agent-manager), kemudian pengelola usaha harus mengembalikan modal utama usaha tersebut berikut bagian profit yang telah sama-sama disepakati oleh kedua pihak yang terikat dalam perjanjian. Sebagai imbalan kerjanya, wakil itu menerima bagian keuntungannya. ${ }^{2}$ Kerugian pada usaha tersebut yang timbul dikarenakan tingginya biaya operasional (di luar perkiraan), maka pengelola usaha sama sekali tidak ikut memikul kerugian tersebut. Pengelola usaha hanya akan mengalami "derita" kerugian karena kehilangan seluruh waktu, tenaga dan pengorbanan pemikirannya dicurahkannya. ${ }^{3}$

Pada abad pertengahan, perjanjian kerjasama (syirkah) dan commenda (mudharabah, qiradh, dan muqaradhah, yang selanjutnya akan digunakan kata mudharabah untuk mewakili semuanya) merupakan dua sarana ekonomi terpenting masyarakat, yang memanfaatkan basis keuangan dan manusia sekaligus untuk memenuhi tujuan perdagangan. Hal-ihwal ini sudah eksis sejak abad pertengahan baik di dunia muslim dan juga di barat. ${ }^{4}$

Melalui akad mudharabah peran penting bank syariah dalam pengentasan kemiskinan akan terlihat karena dengan memberikan pembiayaan mudharabah pada usaha mikro kecil tugas bank syariah sebagai perantara keuangan akan terlihat nyata. Selain itu, melalui akad mudharabah inilah letak bedanya antara

${ }^{1}$ Laila Mugi Harfiah, dkk., "The Impact of ROA, BOPO, and FDR to Indonesia Islamic Bank's Mudharabah Deposit Profit Sharing”, Etikonomi, Vol. 15 (1), April 2016, hlm. 20.

${ }^{2}$ M. Fahim Khan, Essay in Islamic economics (United Kingdom: The Islamic Foundation, 1995), hlm. 80 .

${ }^{3}$ Robert S. Lopez dan Raymond I.W., Medieval Trade in The Mediterranean World (New York: t.tn, 1955), hlm. 175.

4 S.D. Goitein, Commercial and Family Partnerships in The Countries of Medieval Islam, Islamic Studies, 3 (1964), hlm. 315. 
bank berbasis bagi hasil dengan bank berbasis suku bunga akan nyata terlihat. Pembiayaan yang dialirkan melalui akad mudharabah akan melibatkan pihak investor dan pengelola usaha, sebelum kedua kelompok pihak yang berakad ini sepakat berkolaborasi dengan perjanjian mudharabah tentunya akan disetujui porsi bagi hasil antara investor dan pelaksana usaha, pada proses menyetujui porsi bagi hasil inilah letak bedanya. ${ }^{5}$

Bank syariah sudah dikenal sebagai perbankan yang identik dengan bagi hasil. Bagi hasil seharusnya menjadi prinsip mendasar bagi operasional bank syariah. Bagi hasil ini di fiqih muamalah identik melalui perjanjian mudharabah. Melalui akad ini, posisi bank syariah selaku mitra bagi nasabah, baik kepada nasabah penabung dan deposan maupun kepada nasabah yang meminjam dana. Dari sisi funding, bank syariah bertindak sebagai mudharib yang mengelola uang yang diinvestasikan oleh nasabah, sedangkan nasabah menjadi shahibul mal. ${ }^{6}$

Namun, walaupun identik dengan "bank bagi hasil" justru produk yang laris pada perbankan syariah di Indonesia adalah produk murabahah (jual beli). ${ }^{7}$ Bank syariah di Indonesia belum begitu merespon penggunaan skema profit and loss sharing, sehingga sampai sekarang masih menggunakan skema revenuesharing. Penggunaan skema revenue-sharing tersebut karena tingginya kemungkinan moral hazard terjadi di Indonesia. Melalui skema revenue-sharing, bank syariah sebagai pemilik dana dapat menghindari kemungkinan munculnya moral hazard terhadap biaya-biaya usaha dan meminimalisir risiko. ${ }^{8}$

\footnotetext{
${ }^{5}$ Dwi Agung Nugroho Arianto, "Peranan al-Mudharabah Sebagai Salah Satu Produk Perbankan Syariah dalamUpaya Mengentaskan Kemiskinan di Indonesia", Jurnal Ekonomi dan Pendidikan, Vol. 8, No. 2, November 2011, hlm. 168-169

${ }^{6}$ Muhammad Syafi'i Antonio, Bank Syariah: Dari Teori ke Praktek (Jakarta: Gema Insani Press, 2001), hlm. 137.

7 Al-Kaff, Does Islam Assign any Value/Weight to Time Factor in Economic and Financial transactions? (Karachi: Islamic Research Academy, 1986), hlm. 5-6 dan 8.

8 Tarsidin, Bagi Hasil Konsep dan Analisis (Jakarta: Lembaga Penerbit Fakultas Ekonomi Universitas Indonesia, 2010), hlm. 4-5.
} 


\section{Pengertian Mudharabah}

Sebelum zaman Nabi Muhammad SAW terma mudharabah sudah eksis. ${ }^{9}$ Berkaitan dengan hal ini Udovitch menjelaskan bahwa terma mudharabah muncul sebagai bentuk perkongsian di antara daerah semenanjung Arab yang berkembang dalam lingkungan perniagaan pra-Islam. Istilah ini semakin berkembang luas ketika bangsa Arab mampu menaklukkan beberapa wilayah negara-negara Timur Dekat, Afrika Utara sampai ke Eropa Selatan. ${ }^{10}$

Al-Jaziri mengatakan bahwa mudharabah merupakan sebutan bagi tindakan seseorang yang mempercayakan hartanya (dalam bentuk modal investasi) kepada pihak tertentu untuk diperdagangkannya dan membagi keuntungan bagi keduanya berdasarkan kesepakatan. ${ }^{11}$ Mudharabah sangat bermanfaat untuk mobilisasi investasi masyarakat pada pengembangan ekonomi di sektor riil dan untuk menyediakan berbagai fasilitas, antara lain dengan memodali para pelaku bisnis dan memberikan tambahan modal usaha. $^{12}$

Mudharabah berakar dari bahasa Arab yaitu dharb yang artinya adalah menonjok dan memukul serta bepergian (berjalan). Pengertian memukul dan berjalan merupakan kiasan dari "proses seseorang memukulkan dan menghentakkan kedua kakinya dalam suatu usaha". 13 Mudharabah awal mulanya merupakan bahasa sehari-hari dalam tutur kata penduduk Irak, sedangkan menurut tutur kata penduduk Hijaz disebut dengan istilah qiradh atau muqaradhah. ${ }^{14}$

9 Abdullah Saeed, Islamic Banking and Interest, A Study of Prohibition of Riba and Its Contemporary Interpretation (Leiden, New York, Koln: EJ. Brill, 1996), hlm. 51-52.

10 Abraham L Udovitch, Partnership and Profit in Medival Islam (New Jersey: Princeton University Press, 1970), hlm. 172.

11 Abdurrahman al-Jaziri, Kitab al-Fiqh 'ala al-Mazahib al-Arba'ah (Beirut: Dar al-Fikr, t.t.), III: 34, dalam mabahis al-Mudharabah.

12 Nabil A. Saleh, Unlawful Gain and Legitimate Profit in Islamic Law: Riba, Gharar and Islamic Banking (Cambridge: Cambridge University Press, 1986), hlm. 104.

13 Muhammad Usman Syabir, Al-Mu'amalat al-Maliyah al-Mu'ashirah fil Fighi al-Islami (Yordania, Darun Nafais, 1996), hlm. 300.

14 Ali bin Muhammad al-Jumu'ah, Mu'jam al-Musthalahat al-Iqtishadiyah wal Islamiyah (Riyad: Maktabah al-'Abikan, 2000), hlm. 460. 
Secara teknis mudharabah merupakan suatu jenis kerja sama bisnis yang dinaungi oleh akad di antara pihak investor yang menanamkan modal (shahibul mal) dan pihak yang mengelola (mudharib) bisnis, modal seluruhnya bersumber dari pihak investor. ${ }^{15}$ Pembagian keuntungan dari akad mudharabah harus disepakati dalam isi kontrak oleh para pihak yang berakad, dan biasanya dalam bentuk nisbah (persentase). ${ }^{16}$ Sedangkan jika muncul kerugian, maka investor yang akan menanggung kerugian tersebut selama kerugian itu bukan akibat kelalaian pengelola. Jika terjadi kerugian yang diakibatkan oleh karena kecurangan dan kelalaian yang dilakukan pengelola, maka si pengelola wajib bertanggung jawab terhadap kemalangan (rugi) yang ada buah dari kecurangan dan kelalaian yang dilakukannya. ${ }^{17}$ Secara garis besar hal ini senada dengan apa yang sampaikan Warde yaitu bila mudharabah mendapatkan keuntungan; maka keuntungan itu dibagi kepada kedua belah pihak, sedangkan jika rugi; maka kemalangan yang muncul akibat kerugian tersebut ditanggung semuanya oleh pemilik modal. ${ }^{18}$

Menurut Muhammad, fungsi bank dalam kontrak mudharabah adalah menerima dan menyimpan dana shahibul mal serta menyerahkan kepada mudharib yang membutuhkan modal. Artinya, jika shahibul mal ingin mendayagunakan dananya harus melewati bank, begitu juga ketika mudharib menghendaki dana untuk usahanya.

Kerja sama mudharabah dalam sistem perbankan syariah menempatkan bank sebagai mudharib sekaligus sebagai shahibul mal. Selaku pelaksana (mudharib), bank syariah bertugas mengatur dan mengurus dana yang ditaruh deposan untuk mendapatkan porsi pembagian keuntungan. Sedangkan selaku

\footnotetext{
${ }^{15}$ Muhammad, Kebijakan Fiskal dan Moneter dalam Ekonomi Islam (Jakarta: Salemba Empat, 2002), hlm. 69. 224.

${ }^{16}$ Dimyauddin Djuwaini, Pengantar Fiqh Muamalah (Yogyakarta: Pustaka Pelajar, 2008), hlm.

${ }^{17}$ Muhammad Syafi'i Antonio, Bank Syariah dari ..., hlm. 95. hlm. 136.

${ }^{18}$ Ibrahim Warde, Islamic Finance in The Global Economy (Edinburg University Press, 2001),
} 
shahibul mal, bank mendistribusikan dana para deposan kepada debitur untuk diinvestasikan ke dalam bisnis tertentu.

Posisi bank yang berstandar ganda ini tentu sedikit banyak membuat rancu pengertian mudharabah yang dikembangkan oleh ulama fikih. Sebab antara shahibul mal sebagai pemilik modal sesungguhnya dan mudharib (entrepreneur) yang benar-benar mengerahkan tenaga dan keterampilan untuk sebuah bisnis yang riil tidak berjumpa secara terus-menerus dan langsung, tetapi mesti melalui bank.

Sementara bank sebagai lembaga usaha yang bergerak di bidang keuangan yang kegiatan operasionalnya harus didasarkan pada tingkat efisiensi, produktivitas, dan profitabilitas yang layak mempunyai beberapa ketentuan-ketentuan khusus yang mengatur lalu lintas keuangan yang dilakukan oleh shahibul mal dan mudharib. ${ }^{19}$

\section{Sejarah Mudharabah}

Dalam bidang hukum, mudharabah merupakan kontrak kerjasama di mana salah satu mitra (yaitu pemilik) berhak mendapatkan bagian keuntungan karena sebagai investor yang memiliki barang, ia disebut dengan pemilik barang (ras mal); dan mitra lainnya berhak memperoleh bagian keuntungan dari usaha yang dilakukan kerjasama tersebut atas pertimbangan pekerjaan yang dilakukannya dalam mengelola usaha, dan orang ini disebut dharib (atau pengelola) dari kedudukannya itu ia memperoleh bagian keuntungan atas pekerjaannya sendiri dan usahanya. Ia memperoleh kesempatan untuk menggunakan modal berdasarkan kebijaksanaannya sendiri sebaik-baiknya dan berbagai kebijaksanaan dan partisipasi dengan atasan (pemberi modal).

Mudharabah telah ada dan dilakukan oleh umat-umat sebelum Islam datang dan setelah Islam datangpun para sahabat Rasulullah SAW juga

${ }^{19}$ Muhammad, Manajemen Pembiayaan Mudharabah di Bank Syariah: Strategi Memaksimalkan Return dan Meminimalkan Risiko Pembiayaan di Bank Syariah sebagai Akibat Masalah Agency (Jakarta: Rajawali, 2008), hlm. 29-30. 
mempraktekkannya karena mendapatkan manfaat dari kerjasama dengan skema mudharabah ini dan konsep akad ini selaras dengan prinsip dasar syariah. Berdasarkan pendapat Ibnu Rusyd:

" Tidak ada perbedaan pendapat di antara kaum muslim mengenai keabsahan qiradh. Sistem ini pernah sangat digemari pada masa pra Islam dan Islam mengadopsinya. Tidak ada konsensus pendapat bahwa kontrak tersebut mengandung maksud pemberian modal oleh seseorang kepada orang lain untuk keperluan bisnis. Pemakai modal menerima sejumlah proporsi keuntungan yang disepakati, misalnya, proporsi yang mungkin disepakati, sepertiga, seperempat atau bahkan setengahnya."

Nabi Muhammad saw sendiri bekerja sebagai dharib pada transaksi komersial jenis ini kepada Khadijah sebelum beliau diangkat secara resmi sebagai Nabi. ${ }^{20}$ Hal ini dinyatakan oleh Ibn Majah pada pemerintahan Suhaib bahwa muqaradhah merupakan satu dari tiga hal yang diridhoi Allah. Semua ahli hukum Islam sepakat atas keabsahan sebagai suatu bentuk transaksi bisnis dan mereka menyatakan pendapat tersebut berdasarkan banyaknya para sahabat Nabi Muhammad saw yang melakukannya selama masa kehidupan Nabi Muhammad. Nabi Muhammad mengetahui akan praktek tersebut dan menyetujuinya. Dengan begitu, persetujuan Nabi terhadap apa yang dipraktekkan pada masa hidupnya telah menjadi dasar kontrak mudharabah. ${ }^{21}$

Pendapat lain menyatakan bahwa mudharabah dikenal bermula dari dunia Islam ke kota-kota pelabuhan Italia pada akhir abad kesepuluh dan awal abad kesebelas. Meskipun perjanjian-perjanjian perdagangan yang menyerupai mudharabah telah ditemukan ada di Timur Dekat dan kawasan Mediterania semenjak masa permulaan, namun bentuk perjanjian Islam itulah (qiradh, muqaradah, mudharabah) yang menjadi contoh perjanjian perdagangan

${ }^{20}$ Mausu'ah al-Iqtishad al-Islami fil Masharif wan Nuqud wal Aswaq al-Maliyah (Kairo: Darussalam, 2009), I: 299.

${ }^{21}$ Afzalur Rahman, Doktrin Ekonomi Islam, jilid 4, diterjemahkan oleh Soeroyo dan Nastangin (Jakarta: Dana Bhakti Wakaf, 1995), hlm. 380-383. 
permulaan yang identik dengan lembaga resmi ekonomi terkenal di Eropa yang ternama dengan terma commenda. ${ }^{22}$

Besar kemungkinan, mudharabah bersumber dari semenanjung Arab dimana perkembangannya berlangsung di dalam lingkungan kafilah perniagaan orang-orang sebelum Islam. Pada saat ekspansi oleh orang Arab, mudharabah menyebar sampai ke Timur Dekat, Afrika Utara, hingga ke Eropa Selatan. Mudharabah menjadi bahan pembahasan panjang dan terperinci di dalam kitab-kitab fikih permulaan (akhir abad kedelapan). Penjelasan hukum yang terdapat dalam kitab-kitab fikih permulaan itu dapat menegaskan bahwa mudharabah telah berlangsung lama sehingga menjadi lembaga perdagangan yang mapan.

Umar dan Utsman, khalifah kedua dan ketiga adalah sebagian sahabat yang menggunakan mudharabah. Umar pernah menginvestasikan uang anakanak yatim piatu dengan cara bekerjasama dengan para pedagang yang berdagang di antara Madinah dan Irak. Aisyah dan Abdullah bin Umar dulu biasanya menginvestasikan uang anak-anak yatim piatu dan uang lainnya yang ditanganinya melalui sarana mudharabah. Ibn Mas'ud, sahabat terdekat Nabi, dan Abbas bin Abd al-Muttalib paman Nabi ikut andil dalam perdagangan mudharabah. Sedang Abbad mendapatkan persetujuan Nabi saw atas tindakannya menetapkan syarat kepada wakil yang dipercayainya mampu mengelola uangnya. Dua putra Umar menggunakan uang pajak kedaerahan yang dipungutnya dalam perjalanan mereka menuju ibukota kekhalifahan pertama di Madinah, kerja sama mudharabah tersebut terwujud melalui barang yang dibeli di Irak kemudian diperdagangkan di Madinah. Mereka menyimpan separuh keuntungan untuk diri mereka sendiri dan mengembalikan besaran pokoknya berikut dengan sisa keuntungannya untuk kekayaan negara. ${ }^{23}$

22 Jusmaliani dkk., Bisnis Berbasis Syariah (Jakarta: Bumi Aksara, 2008), hlm. 209-210.

${ }^{23}$ Abraham L. Udovitch, Kerjasama Syariah dan Bagi Untung-Rugi dalam Sejarah Islam Abad Pertengahan (Teori dan Penerapannya), diterjemahkan oleh Syafrudin Arif Marah Manunggal (Kediri: Qubah, 2008), hlm. 234-236. 


\section{Bentuk Akad Mudharabah}

Kata akad berasal dari bahasa Arab, yang lazimnya di sebut 'aqada dari kata 'aqada, ya'qidu, 'aqdan, yang berarti mengikat dan mengumpulkan. ${ }^{24} \mathrm{Akad}$ yang asal katanya mengikat dan mengumpulkan ini; pengertiannya adalah mengumpulkan ujung dua buah tali dan menghubungkan dua ujung tali tersebut dalam satu ikatan sehingga saling bersambung, kemudian keduanya bersambung menjadi sepotong benda. ${ }^{25}$

Akad atau perjanjian adalah suatu ikatan antara dua pihak atau lebih tentang sesuatu urusan tertentu yang dimulai dengan kehendak salah satu pihak kemudian disetujui oleh pihak di sisi lainnya yang ikut serta dalam perjanjian tersebut dan akhirnya memunculkan pemufakatan di antara pihakpihak yang ikut serta dalam perjanjian. ${ }^{26}$

Adapun menurut istilah syara', As-Sanhury dalam kitabnya Nazariyyah al-'Aqd Syarh al-Qanun mengutip dari kitab Mursyid al-Hairan mengemukakan bahwa yang di maksud dengan akad (perjanjian) adalah suatu perbuatan yang dilandasi dengan hukum di mana seorang atau lebih melakukan perjanjiaan dan mengikatkan dirinya terhadap beberapa orang. ${ }^{27}$ Menurut Ahmad Azhar Basyir akad adalah suatu komitmen ijab kabul dengan aturan yang telah diluruskan oleh syara' dan melahirkan konsekuensi hukum pada obyeknya. ${ }^{28}$

Menurut Husein Hamid Hasan sebagaimana di kutip oleh Niazi mendefinisikan akad adalah penghubung dua hal yaitu penawaran (ijab) dan penerimaan (qabul). Sedangkan Edward William Lane menyatakan bahwa akad adalah kontrak, kesepakatan, perjanjian, persetujuan, ikatan, fakta, dan

24 Ahmad Warson Munawwir, Al-Munawwir Kamus Arab Indonesia, (Yogyakarta: PP alMunawwir Krapyak, 1984), hlm. 1023.

${ }^{25}$ S. E. Rayner, The Theory of Contract in Islamic Law (London: Bordrecht/Boston: Graham and Trorman, 1991), hlm. 5.

${ }^{26}$ Ibid..., hlm. 13.

27 Abd. Ar-Razzaq as-Sanhury, Nadzariyahal- 'Aqd (Beirut: Dar al-Fikr, t.t.), hlm. 80.

28 Ahmad Azhar Basyir, Asas-asas Hukum Mu'amalat (Hukum Perdata Islam) (Yogyakarta: Perpustakaan Fakultas Hukum UII, 1993), hlm. 42. 
pertunangan. ${ }^{29}$ Sedangkan menurut Mursyid al-Huraian akad berarti penawaran yang berasal dari satu diantara dua orang atau kelompok yang melakukan kontrak; dimana pihak kedua setuju dengan materi kontrak yang diajukan oleh pihak pertama. ${ }^{30}$

Aktualisasi perjanjian di antara beberapa pihak yang terlibat dalam komitmen perjanjian wajib berpegang atas prinsip ketulusan (ikhtiyari), menunaikan komitmen ('amanah), siaga dan kehati-hatian (ihtiyati), konstan (luzum), sama-sama bermanfaat, ekuivalen (taswiyah), terbuka, tidak sulit (taisir), bertujuan untuk kebaikan, menjunjung tinggi kehalalan. Asas-asas ini sinkron dengan hukum positif yang terdapat di Indonesia.

Sebelum dibahas lebih dalam tentang akad mudharabah ini, akan dilihat terlebih dahulu beberapa pendapat ilmuwan muslim yang mempertanyakan validitas mudharabah sebagai dasar bagi kegiatan perbankan Islam (pendapat ini dipaparkan hanya untuk memperkaya wacana saja, penulis tidak sepakat dengan pendapat ini). ${ }^{31}$ Sejumlah ilmuwan muslim tidak sepakat seandainya mudharabah digunakan sebagai basis bagi aktivitas perbankan Islam dengan argumentasi:

1. Karena akad perjanjian mudharabah telah eksis dan berkembang sejak abad pertengahan dan cocok kondisi tertentu pada saat itu. Akad ini tidak mempunyai landasan hukum yang kuat untuk bisa diaplikasikan dalam aktivitas-aktivitas keuangan modern dalam masyarakat industri yang kompleks. Pendapat ini didasarkan kepada asumsi bahwa para ahli hukum dan ahli teologi Islam mutakhir tidak memiliki hak untuk melakukan penafsiran ulang atas asas-asas hukum yang terdahulu, yang telah menjadi ijtihad. Dengan kata lain, mudharabah yang dikembangkan di abad pertengahan adalah untuk

${ }^{29}$ Liaquat Ali Khan Niazi, Islamic Law of Contract (Lahore: Research Cell, t.t.), hlm. 9.

${ }^{30}$ Ibid ..., hlm. 10.

${ }^{31}$ Elias G. Kazarian dkk., Islamic Versus Traditional Banking, Financial Inovation in Egypt (Boulde: Westview Press, 1993), hlm. 63. 
waktu dan untuk keadaan ekonomi pada waktu itu dan karena berlakunya berdasarkan ijtihad para ulama atau para ahli hukum dan para ahli teologi muslim pada waktu itu, tidak dapat ditafsirkan atau dimodifikasikan oleh para ahli hukum dan ahli teologi muslim masa kini untuk keadaan ekonomi atau untuk keperluan pada waktu kini yang telah berbeda dengan keadaan ekonomi para abad pertengahan.

2. Perjanjian mudharabah juga tidak diterima berlandaskan dalih politisideologis (politic-ideological grounds). Menurut pendapat mereka bahwa bank-bank Islam, yang didirikan oleh para kapitalis muslim, akan mengeksploitasi para penabung kecil melalui penggunaan instrumeninstrumen keuangan yang agamis sebagai sarana legal para pemegang saham dari bank-bank Islam akan menggunakan dana-dana dari para penyimpan dana yang kecil untuk mendapatkan laba setinggitingginya dengan melenyapkan risiko yang mengancam kapitalis muslim. Sebagaimana ketentuan mudharabah, risiko bank yang terjelek yang akan dialaminya sebagai mudharib bila terjadi kerugian atas transaksi mudharabah itu ialah hanya sekedar berupa tidak menerima renumerasi atas jerih payahnya, bukan berupa memikul risiko finansial. ${ }^{32}$

Dengan mengesampingkan keraguan beberapa ilmuwan muslim di atas, sebenarnya para ahli hukum Islam (khususnya empat imam Sunni) telah sepakat menyatakan bahwa kontrak mudharabah sah dan diperbolehkan menurut Islam dengan memenuhi persyaratan sebagai berikut:

1. Mudharabah bisa diterapkan bila dua orang atau lebih minus paksaan dan atas keinginan mereka sendiri menyelenggarakan suatu perjanjian di mana salah seorang menyerahkan beberapa investasinya

${ }^{32}$ Ibid., hlm. 63-64. 
sebagai modal bagi pihak lain yang mengurus modal tersebut di sektor bisnis untuk mendapatkan laba yang berguna untuk kerja sama tersebut.

2. Seluruh kelompok dan individu yang terlibat dalam kolaborasi akad perjanjian mudharabah wajib mengerti dan paham detail-detail persentase pembagian keuntungan untuk masing-masing. Sementara itu bila muncul celaka (rugi) maka pelaksana (mudharib) tidak memperoleh kompensasi apapun dari hasil pengelolaan yang sudah dilakukannya dan kerugian yang muncul tersebut semuanya menjadi tanggung jawab investor. ${ }^{33}$

3. Modal digenggam oleh pihak lain (misalnya manajer) untuk maksud mudharabah.

4. Mudharib secara bebas sepenuhnya dapat berbisnis dengan menggunakan modal yang dipercayakan kepadanya dan mengambil langkah-langkah yang ia anggap perlu juga cermat demi memperoleh laba setinggi-tingginya.

5. Pihak-pihak yang terlibat dalam kerjasama masing-masing berhak menentukan lamanya jangka waktu kemitraan dengan memberitahukan pada pihak lainnya. Namun, untuk melindungi hak semua pihak, dan untuk menjamin hasil keuntungan yang maksimum bagi semua pihak (hal yang sangat mendasar dalam kemitraan), maka sangat diperlukan untuk menentukan jangka waktu minimum kerjasama mudharabah. ${ }^{34}$

${ }^{33}$ Muhammad Nejatullah Siddiqi, Aspek-aspek Ekonomi Islam, diterjemahkan oleh Dewi P. Restiana (Solo: CV. Ramadhani, 1991), hlm. 75.

${ }^{34}$ Afzalur Rahman, Doktrin Ekonomi Islam..., IV: 383-385. 
Di bank syariah, akad mudharabah terbagi pada produk penghimpunan dana dan penyaluran dana. Keduanya menekankan bagi hasil bagi shahibul mal dan mudharib.

\section{Penghimpunan Dana}

Pada produk ini mudharabah adalah akad antara pihak pemilik modal (shahibul mal) dengan pengelola (mudharib) untuk memperoleh pendapatan atau keuntungan. Keuntungan yang diperoleh diberikan kepada masing-masing pihak yang berakad sesuai dengan nisbah para pihak yang berakad (biasanya tertuang dalam isi akad). Aplikasinya dalam perbankan syariah pada penghimpunan dana, yaitu pada deposito dan tabungan. Di sini, antara bank dan nasabah penabung dan deposan sudah melaksanakan konsensus di awal perjanjian perihal nisbah bagi hasil. Dana yang diinvestasikan nasabah di bank baik berupa deposito maupun tabungan, akan dikelola pihak perbankan untuk menghasilkan profit. Hasil dari pengelolaannya itulah yang kemudian harus dibagikan di antara bank dan nasabah. ${ }^{35}$

2. Penyaluran dana

Pada produk ini mudharabah ${ }^{36}$ merupakan pembiayaan yang disalurkan oleh bank syariah bagi nasabah yang membutuhkan pinjaman pembiayaan yang biasanya untuk sasaran produktif misalnya bagi modal bisnis. Laba yang didapat dari bisnis yang dimodali lewat pembiayaan bank syariah tersebut akan dialokasikan sesuai dengan konsensus dalam perjanjian melalui bagian proporsi bagi hasil untuk masing-masing pihak. Biasanya porsi bagi hasil

${ }^{35}$ Ahmad Azhar Basyir, Asas-asas ..., hlm. 130.

${ }^{36}$ Mudharabah dari sisi penyaluran dana ini dikenal juga dengan pembiayaan berdasarkan akad bagi hasil. Dalam praktik perbankan syariah dikenal dua macam pembiayaan yang didasarkan pada akad bagi hasil ini, yaitu pembiayaan mudharabah dan pembiayaan musyarakah. Dikutip dari Abdul Ghofur Anshori, Penerapan Prinsip Syariah Dalam Lembaga Keuangan, Lembaga Pembiayaan dan Perusahaan Pembiayaan (Yogyakarta: Pustaka Pelajar, 2008), hlm. 22. 
untuk mudharib lebih banyak (tinggi) dibandingkan dengan porsi bagi hasil untuk shahibul mal. Ketika pembiayaan berakhir karena sudah mencapai limit waktu, dana pembiayaan yang dipinjam oleh nasabah harus dilunasi dan dikembalikan kepada bank yang menyalurkan pembiayaan. ${ }^{37}$

\section{Mekanisme Mudharabah di Perbankan Syariah}

Penerbitan suatu produk perbankan syariah berkaitan erat dengan masalah regulasi dan sumber daya manusia. Jika perbankan syariah di Indonesia diberikan kebebasan berinovasi pada pengembangan produknya, maka produknya akan variatif mengikuti produk-produk hukum syariah. Perbankan syariah yang produknya tidak berhubungan dengan suku bunga akan memberikan dampak bagi kestabilan mata uang. Sebab, perbankan syariah tak terpisahkan dari perannya dalam pengembangan sektor riil. Produk perbankan syariah tidak mengakibatkan bubble economics. ${ }^{38}$ Karakter ideal produk perbankan syariah diintrodusir dari prinsip muamalat, aplikatif dengan akad praktis, memenuhi kebutuhan konsumen, punya daya saing di dunia perbankan, dan mengikuti perkembangan zaman. Ini berarti bahwa setiap produk perbankan syariah dieksplorasi dari prinsip-prinsip normatif yang ada dalam al-Qur'an, hadis, dan berbagai khazanah fiqh. Itupun belum cukup, prinsip normatif harus dipersandingkan, dikomparasikan, dan dicarikan legitimasi ekonomisnya dalam khazanah term-term perbankan kovensional. ${ }^{39}$

Menurut Abdullah Saeed, kontrak mudharabah di perbankan syariah sebagian besar digunakan untuk tujuan komersil jangka pendek dan untuk usaha tertentu. Nasabah bank syariah dapat masuk ke kontrak mudharabah

\footnotetext{
${ }^{37}$ Ibid..., hlm. 152 dan 154.

38 Zainul Arifin, Memahami Bank Syariah: Lingkup Peluang Tantangan dan Prospek (Jakarta: Alvabet, 1999), hlm. 198.

${ }^{39}$ M. Nur Yasin, Hukum Ekonomi Islam: Geliat Perbankan Syariah di Indonesia (Malang: UIN Malang Press, 2009), hlm. 1-2.
} 
hanya melalui bank. Mudharib (klien), akan memperoleh bantuan pembiayaan dari bank (ketika sudah menandatangani kontrak). Calon mudharib juga harus menyampaikan kepada bank laporan keuangan yang diperlukan mengenai harga jual yang diharapkan, arus kas dan marjin keuntungan, di mana bank akan melakukan peninjauan sebelum membuat keputusan terkait dengan pembiayaan. Bank biasanya akan menyediakan pembiayaan yang diperlukan jika sesuai dengan marjin keuntungan yang diharapkan oleh bank. ${ }^{40}$

Aplikasi bentuk bagi hasil (mudharabah) dalam skim bank syariah adalah:

1. Rekening Tabungan

Aplikasinya bank syariah memperoleh dana simpanan nasabah yang menyimpan uangnya dalam bentuk tabungan, kemudian menyepakati dengan nasabah tersebut akad apa yang akan digunakan. Prinsip yang dapat digunakan melalui produk ini adalah:

a. Wadi'ah atau titipan

b. Qardh atau pinjaman hutang

c. Mudharabah atau bagi hasil.

Ada sedikit perbedaan antara wadi'ah yang digunakan untuk rekening tabungan, dan wadi'ah yang digunakan untuk rekening giro. Di dalam wadi'ah bagi rekening tabungan, bank bisa membagikan bonus untuk nasabah dari laba yang didapat bank disebabkan bank lebih bebas untuk memanfaatkan dana ini untuk tujuan mendapatkan laba. Qardh merupakan pinjaman berupa hutang. Dalam hal ini, bank seperti mendapat pinjaman tanpa bunga dari deposan. Bank dapat menggunakan dana ini untuk tujuan apa saja, dan dari keuntungan yang diperoleh bank dapat memberikan bagian keuntungan kepada deposan berupa uang atau non uang (hal ini jarang terlihat dalam

${ }^{40}$ Abdullah Saeed, Islamic Banking ..., hlm. 56. 
praktik). Selain itu, bank juga bisa menggabungkan rekening tabungan bersama rekening investasi melalui asas akad mudharabah muthlaqah, atau ringkasnya disebut dengan mudharabah melalui bagi hasil yang disepakati bersama.

2. Rekening Investasi Umum (Investasi Tidak Terikat)

Bank syariah mengimplementasikan asas akad mudharabah almuthlaqah pada rekening investasi umum dalam format deposito berjangka. Investasi umum ini terkadang dinamakan juga dengan investasi tidak terikat, rekening investasinya dimaksudkan untuk berburu laba daripada untuk menyelamatkan uangnya. Melalui akad mudharabah al-muthlaqah bank syariah yang berperan sebagai pengelola dana nasabah bebas (mempunyai kewenangan mutlak) dan tidak diikat oleh syarat apapun dalam mengelola dana yang diinvestasikan oleh nasabah.

3. Rekening Investasi Khusus (Investasi Terikat)

Selain mudharabah muthlaqah, di bank syariah juga terdapat prinsip mudharabah al-muqayyadah melalui rekening investasi khusus (special investment account) atau ternama juga melalui investasi tertawan (terikat). Rekening investasi khusus ini lazimnya diperuntukkan bagi para nasabah/investor yang menginvestasikan modalnya dalam jumlah besar dan institusi. Melalui skema mudharabah al-muqayyadah ini bank syariah tidak punya kewenangan mutlak dalam pengelolaan dana yang diinvestasikan oleh nasabah karena diikat oleh syaratsyarat tertentu oleh nasabah yang mengivestasikan dananya dalam jumlah besar. ${ }^{41}$

${ }^{41}$ Veithzal Rivai dkk., Bank and Financial Institution Management: Conventional and Sharia System (Jakarta: PT. Raja Grafinso Persada, 2007), hlm. 765-766. 


\section{Sukuk Mudharabah}

Akad mudharabah juga bisa digunakan oleh bank syariah untuk menampung dana lewat obligasi syariah. Dengan obligasi syariah (sukuk), bank memperoleh kepastian investasi dalam jangka panjang karena investasi yang ditanamkan nasabah obligasi syariah berjangka waktu lima tahun ataupun lebih lama. ${ }^{42}$ Dalam hal sukuk mudharabah, pada umumnya sulit didapat kepastian akan hasil investasi maupun pengembalian modal awal. Oleh karena itu, diperlukan inovasi untuk mengidentifikasi usaha spesifik yang akan dibiayai serta unsur biaya tetap, biaya variabel dan unsur pendapatan yang berkaitan. ${ }^{43}$

Bank syariah mempunyai potensi besar untuk berkembang sebagai bank yang mampu mengalihkan potensi pertumbuhan ekonomi dari riba, maysir dan gharar. Apalagi dengan akad mudharabah yang menerapkan profit and loss sharing perbankan syariah akan menjadi lokomotif perbankan yang berbasis keadilan, meniadakan penindasan dan melawan kapitalisme yang hanya menguntungkan para pemilik modal dan hanya menyejahterakan orang kaya (pemilik modal).

Namun, problemnya adalah akad mudharabah tidak begitu diminati di perbankan syariah. Bukan hanya di perbankan syariah Indonesia akad mudharabah kurang diminati; tapi juga pada perbankan syariah di Malaysia. Akad mudharabah dan musyarakah di Malaysia hanya menyumbang 6\% dari keseluruhan transaksi yang ada pada perbankan syariah di Malaysia. Padahal konsep "mulia" perbankan syariah untuk menegakkan keadilan dari sistem

42 Ascarya, Akad dan Produk Bank Syariah (Jakarta: PT. Raja Grafindo Persada, 2008), hlm. 119.

43 Adrian Sutedi, Pasar Modal Syariah: Sarana Investasi Keuangan Berdasarkan Prinsip Syariah (Jakarta: Sinar Grafika, 2011), hlm. 205. 
riba dan menghilangkan kesenjangan antara orang yang berharta dan fakir terdapat pada konsep akad perjanjian mudharabah dan akad musyarakah. ${ }^{44}$

Kurang diminatinya pembiayaan mudharabah pada Bank Umum Syariah dan Unit Usaha Syariah di Indonesia terlihat pada data berikut ini:

\section{Gambar 1:}

Pembiayaan oleh

Bank Umum Syariah (BUS) dan Unit Usaha Syariah (UUS)

\section{di Indonesia}

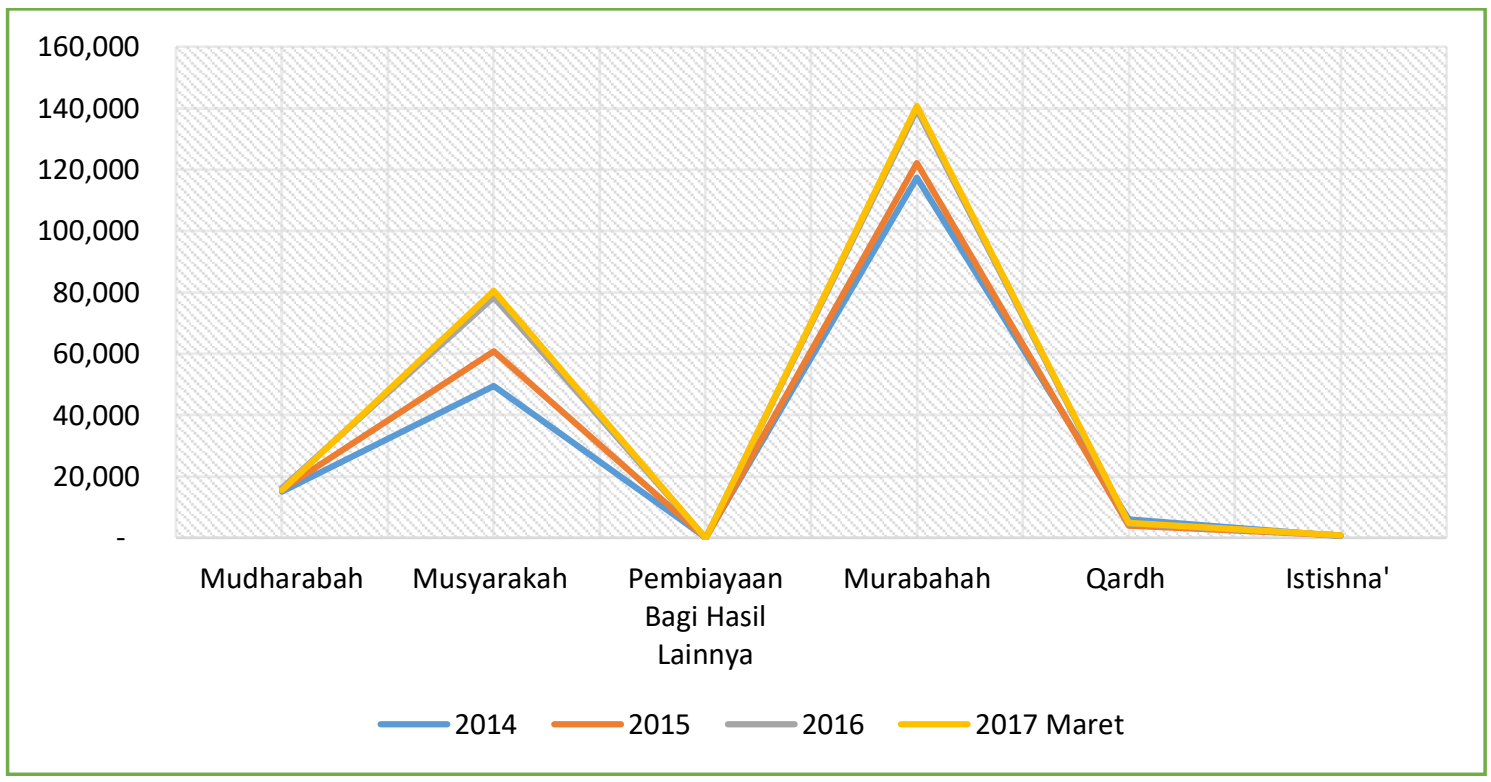

Sumber: Otoritas Jasa Keuangan, 2017

Data pembiayaan pada gambar $1 \mathrm{di}$ atas mengungkapkan bahwasanya pembiayaan murabahah menjadi pembiayaan yang paling melimpah penyalurannya dan yang paling menarik animo masyarakat yang mengajukan pinjaman pembiayaan pada perbankan syariah di Indonesia (khususnya BUS dan UUS). Pada tahun 2014 saja pembiayaan murabahah sudah sangat tinggi menarik animo nasabah perbankan syariah (dengan angka lebih kurang Rp 117

44 Aisyah Abdul-Rahman dan Shifa Mohd Nor, "Challenges of Profit and Loss Sharing Financing in Malaysian Islamic Banking”, GEOGRAFIA Online TM: Malaysian Journal of Society and Space, Space 12, Issue 2, 2016, hlm.39-40. 
Triliun), bahkan sampai dengan bulan Maret tahun 2017 pembiayaan murabahah terus konsisten menduduki posisi tertinggi sebagai pembiayaan paling laris disalurkan oleh perbankan syariah (dengan angka lebih kurang Rp 140 Triliun).

Berbeda dengan akad murabahah, akad mudharabah justru menduduki posisi ketiga terlaris setelah akad murabahah dan akad musyarakah. Pada tahun 2014 pinjaman pembiayaan melalui akad perjanjian mudharabah hanya disalurkan sebanyak Rp 15 Triliun, hingga bulan Maret tahun 2017 pembiayaan mudharabah yang disalurkan sekitar Rp 15,4 Triliun. Jika diamati berdasarkan banyaknya pembiayaan yang digulirkan di antara akad mudharabah dan akad murabahah terlihat pembiayaan mudharabah sangat jauh ketinggalan.

Akan tetapi bila dikomparasikan atas pinjaman pembiayaan musyarakah yang sama-sama berlandaskan asas bagi hasil melalui akad mudharabah tampak pembiayaan musyarakah meningkat sangat baik. Di mana data tahun 2014 memperlihatkan pembiayaan yang dicairkan dengan akad pinjaman musyarakah berjumlah Rp 49 Triliun dan pada Maret 2017 pinjaman musyarakah yang disalurkan lebih kurang Rp 80 Triliun. Jika dibandingkan antara tahun 2014 dan tahun 2017 terlihat pembiayaan musyarakah bertambah sangat siginifikan bahkan hampir dua kali lipat.

Dominannya pembiayaan murabahah atas pinjaman melalui asas prinsip bagi hasil baik melalui akad mudharabah maupun akad musyarakah bukan hanya terjadi di Bank Umum Syariah dan Unit Usaha Syariah, tapi juga di Bank Pembiayaan Rakyat Syariah. Data berikut ini membuktikan hal tersebut: 


\section{Gambar 2:}

\section{Pembiayaan oleh Bank Pembiayaan Rakyat Syariah (BPRS)} di Indonesia

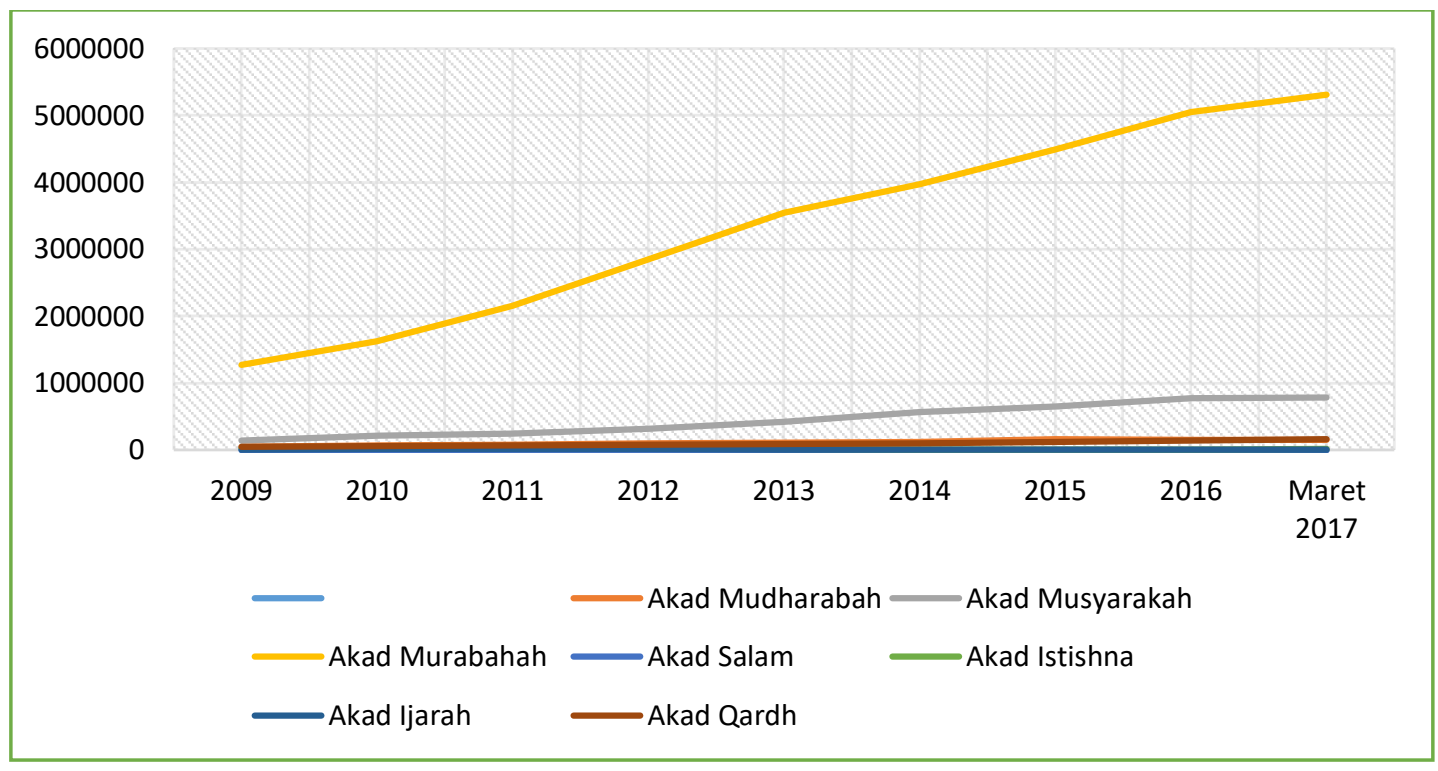

Sumber: Otoritas Jasa Keuangan, 2017

Data pembiayaan yang dicairkan oleh Bank Pembiayaan Rakyat Syariah (BPRS) di Indonesia dari tahun 2009 sampai dengan Maret 2017 juga memperlihatkan dominannya perjanjian kontrak (akad) murabahah pada BPRS. Pada tahun 2009 jumlah total pinjaman yang dicairkan dengan akad murabahah disalurkan sebanyak Rp 1,2 Triliun dan pada Maret 2017 pembiayaan murabahah yang disalurkan berjumlah Rp 5,3 Triliun. Dalam rentang delapan tahun pembiayaan murabahah yang dicairkan melalui BPRS meningkat hampir empat kali lipat.

Sementara itu posisi pinjaman pembiayaan dengan akad mudharabah di BPRS sama dengan posisi pembiayaan yang terdaapt pada BUS dan UUS yakni menduduki peringkat ketiga sebagai pinjaman pembiayaan yang paling menarik animo masyarakat. Tahun 2009 jumlah pembiayaan mudharabah yang disalurkan BPRS berjumlah Rp 52 Miliar dan pada Maret 2017 berjumlah Rp 
150 Miliar, jumlah pembiayaan mudharabah yang dicairkan melalui BPRS selama delapan tahun terlihat meningkat nyaris tiga kali lipat.

Peringkat kedua pembiayaan terlaris di BPRS ditempati oleh akad musyarakah, data tahun 2009 nominal pinjaman pembiayaan musyarakah yang dicairkan oleh BPRS berjumlah Rp 144 Miliar dan pada Maret 2017 berjumlah Rp 783 Miliar. Pembiayaan dengan akad musyarakah yang disampaikan oleh BPRS selama delapan tahun meningkat lima kali lipat. 45

Sangat disayangkan memang akad pinjaman pembiayaan mudharabah dan akad musyarakah masih belum bisa bersaing dengan akad murabahah padahal melalui pinjaman pembiayaan bagi hasil inilah bank syariah diharapkan bisa berfungsi selaku bank yang peka kepada sosioekonomi. Bahkan menurut Khan dan Bhatti yang dikutip oleh Ernawati sistem profit and loss sharing yang ada di akad pinjaman pembiayaan mudharabah dan akad musyarakah merupakan jantungnya intermediasi keuangan Islam. Dalam sudut pandang manajemen risiko, pembiayaan mudharabah dan musyarakah merupakan pembiayaan yang sangat rentan dan riskan terhadap risiko di bank syariah sehingga bank syariah mengambil jalan menjauhi risiko dan hal inilah yang menyebabkan pinjaman pembiayaan melalui akad mudharabah dan akad musyarakah tidak begitu banyak disalurkan. ${ }^{46}$

Tariqullah Khan dan Habib Ahmed membenarkan bahwa produk bank syariah yang sangat riskan dengan risiko yaitu pembiayaan dengan akad musyarakah dan pembiayaan dengan akad mudharabah serta produk yang paling kecil risikonya adalah pembiayaan murabahah. 47 Namun, walaupun pinjaman pembiayaan dengan akad mudharabah dan musyarakah ini yang paling berisiko; perlu dipikirkan solusi dan langkah strategis agar pinjaman dengan akad

${ }^{45}$ Otoritas Jasa Keuangan, Statistik Perbankan Syariah Maret 2017.

46 Ernawati, "Risk of Profit and Loss Sharing Financing: The Case of Indonesia", Al-Iqtishad: Journal of Islamic Economics, Vol. 8 (1), Januari 2016, hlm. 105.

${ }^{47}$ Tariqullah Khan dan Habib Ahmed, Risk Management: An Analysis of Issuess in Islamic Financial Industry: Occasional Paper, No.5, Jeddah: Lembaga Pelatihan dan Riset Islamic Development Bank, tahun 2001, hlm. 59. 
Hendra Cipta

mudharabah dan musyarakah semakin diperhatikan dan dapat sejajar dengan pembiayaan murabahah. Karena melalui mudharabah dan musyarakah inilah peran bank syariah dalam mengembangkan ekonomi umat akan diperhitungkan.

\section{Kesimpulan}

Mudharabah merupakan akad pinjaman yang memfasilitasi pemberian pembiayaan untuk permodalan usaha (tujuan produktif). Hubungan yang terjalin antara nasabah dengan bank syariah melalui akad ini adalah rekanan (mitra) bukan hubungan antara penghutang dan peminjam hutang. Pembagian keuntungan (bagi hasil) akad ini berdasarkan persentase pembagian keuntungan (bagi hasil) yang telah disetujui antara pihak yang saling berkolaborasi dalam suatu bisnis. Biasanya kesepakatan ini tertuang dalam akad yang disetujui para pihak sejak pertama kali akad berlangsung.

Walaupun sekarang perbankan syariah yang sudah eksis di Indonesia baru bisa mempraktekkan pembagian keuntungan melalui skema revenue sharing; belum dalam skema profit and loss sharing. Namun, harus ada optimisme bahwa suatu saat bank-bank syariah yang sudah eksis dan yang akan eksis di Indonesia mampu melaksanakan pembagian keuntungan dalam skema profit and loss sharing. 


\section{DAFTAR PUSTAKA}

Al-Kaff, Does Islam Assign any Value/Weight to Time Factor in Economic and Financial transactions?, Karachi: Islamic Research Academy, 1986.

Anshori, Abdul Ghofur, Penerapan Prinsip Syariah Dalam Lembaga Keuangan, Lembaga Pembiayaan dan Perusahaan Pembiayaan, Yogyakarta: Pustaka Pelajar, 2008.

Antonio, Muhammad Syafi'I, Bank Syariah dari Teori ke Praktek, Jakarta: Gema Insani Press, 2001.

Arianto, Dwi Agung Nugroho, "Peranan al-Mudharabah Sebagai Salah Satu Produk Perbankan Syariah dalamUpaya Mengentaskan Kemiskinan di Indonesia", Jurnal Ekonomi dan Pendidikan, Vol. 8, No. 2, November 2011.

Arifin, Zainul, Memahami Bank Syariah: Lingkup Peluang Tantangan dan Prospek, Jakarta: Alvabet, 1999.

Ascarya, Akad dan Produk Bank Syariah, Jakarta: PT. Raja Grafindo Persada, 2008.

Basyir, Ahmad Azhar, Asas-asas Hukum Mu'amalat (Hukum Perdata Islam), Yogyakarta: Perpustakaan Fakultas Hukum UII, 1993.

Djuwaini, Dimyauddin, Pengantar Figh Muamalah, Yogyakarta: Pustaka Pelajar, 2008.

Ernawati, "Risk of Profit and Loss Sharing Financing: The Case of Indonesia", Al-Iqtishad: Journal of Islamic Economics, Vol. 8 (1), Januari 2016.

Goitein, S.D., Commercial and Family Partnerships in The Countries of Medieval Islam, Islamic Studies, 3, 1964.

Harfiah, Laila Mugi, dkk., "The Impact of ROA, BOPO, and FDR to Indonesia Islamic Bank's Mudharabah Deposit Profit Sharing", Etikonomi, Vol. 15 (1), April 2016.

Jaziri, Abdurrahman al-, Kitab al-Figh 'ala al-Mazahib al-Arba'ah, juz. III, Beirut: Dar al-Fikr, t.t., dalam mabahis al-Mudharabah.

Jumu'ah, Ali bin Muhammad al-, Mu'jam al-Musthalahat al-Iqtishadiyah wal Islamiyah, Riyad: Maktabah al-'Abikan, 2000. 
Jusmaliani dkk., Bisnis Berbasis Syariah, Jakarta: Bumi Aksara, 2008.

Kazarian, Elias G. dkk., Islamic Versus Traditional Banking, Financial Inovation in Egypt, Boulde: Westview Press, 1993.

Khan, M. Fahim, Essay in Islamic economics, United Kingdom: The Islamic Foundation, 1995.

Tariqullah Khan dan Habib Ahmed, Risk Management: An Analysis of Issuess in Islamic Financial Industry: Occasional Paper, No.5, Jeddah: Lembaga Pelatihan dan Riset Islamic Development Bank, tahun 2001.

Lopez, Robert S. dan Raymond I.W., Medieval Trade in The Mediterranean World, New York: t.tn, 1955.

Mausu'ah al-Iqtishad al-Islami fil Masharif wan Nuqud wal Aswaq al-Maliyah, jilid I, Kairo: Darussalam, 2009.

Muhammad, Kebijakan Fiskal dan Moneter dalam Ekonomi Islam, Jakarta: Salemba Empat, 2002.

Manajemen Pembiayaan Mudharabah di Bank Syariah: Strategi Memaksimalkan Return dan Meminimalkan Risiko Pembiayaan di Bank Syariah sebagai Akibat Masalah Agency, Jakarta: Rajawali, 2008.

Munawwir, Ahmad Warson, Al-Munawwir Kamus Arab Indonesia, Yogyakarta: PP al-Munawwir Krapyak, 1984.

Niazi, Liaquat Ali Khan, Islamic Law of Contract, Lahore: Research Cell, t.t.

Otoritas Jasa Keuangan, Statistik Perbankan Syariah Maret 2017.

Rahman, Aisyah Abdul dan Shifa Mohd Nor, "Challenges of Profit and Loss Sharing Financing in Malaysian Islamic Banking", GEOGRAFIA Online TM: Malaysian Journal of Society and Space, Space 12, Issue 2, 2016.

Rahman, Afzalur, Doktrin Ekonomi Islam, jilid 4, diterjemahkan oleh Soeroyo dan Nastangin, Jakarta: Dana Bhakti Wakaf, 1995.

Rivai, Veithzal dkk., Bank and Financial Institution Management: Conventional and Sharia System, Jakarta: PT. Raja Grafindo Persada, 2007. 
Saeed, Abdullah, Islamic Banking and Interest, A Study of Prohibition of Riba and Its Contemporary Interpretation, Leiden, New York, Koln: EJ. Brill, 1996.

Saleh, Nabil A., Unlawful Gain and Legitimate Profit in Islamic Law: Riba, Gharar and Islamic Banking, Cambridge: Cambridge University Press, 1986.

Sanhury, Abd. Ar-Razzaq as-, Nadzariyahal-'Aqd, Beirut: Dar al-Fikr, t.t.

S. E. Rayner, The Theory of Contract in Islamic Law, London: Bordrecht/Boston: Graham and Trorman, 1991.

Siddiqi M. Nejatullah, Aspek-aspek Ekonomi Islam, diterjemahkan oleh Dewi P. Restiana, Solo: CV. Ramadhani, 1991.

Sutedi, Adrian, Pasar Modal Syariah: Sarana Investasi Keuangan Berdasarkan Prinsip Syariah, Jakarta: Sinar Grafika, 2011.

Syabir, Muhammad Usman, Al-Mu'amalat al-Maliyah al-Mu'ashirah fil Fighi alIslami, Yordania, Darun Nafais, 1996.

Tarsidin, Bagi Hasil Konsep dan Analisis, Jakarta: Lembaga Penerbit Fakultas Ekonomi Universitas Indonesia, 2010.

Udovitch, Abraham L., Partnership and Profit in Medival Islam, New Jersey: Princeton University Press, 1970.

Kerjasama Syariah dan Bagi Untung-Rugi dalam Sejarah Islam Abad Pertengahan (Teori dan Penerapannya), diterjemahkan oleh Syafrudin Arif Marah Manunggal, Kediri: Qubah, 2008.

Warde, Ibrahim, Islamic Finance in The Global Economy, Edinburg University Press, 2001.

Yasin, M. Nur, Hukum Ekonomi Islam: Geliat Perbankan Syariah di Indonesia, Malang: UIN Malang Press, 2009. 